\title{
Article/Artigo
}

\section{Hydrophobic fraction of Taenia saginata metacestodes, rather than hydrophilic fraction, contains immunodominant markers for diagnosing human neurocysticercosis}

\author{
Fração hidrofóbica de metacestódeos de Taenia saginata, ao contrário da fração hidrofílica, \\ contém marcadores imunodominantes para o diagnóstico de neurocisticercose humana
}

\author{
Flávia de Assunção Gonçalves ${ }^{1}$, Gleyce Alves Machado ${ }^{1,2}$, Heliana Batista Oliveira ${ }^{1,2}$, Maria Teresa Nunes \\ Pacheco Rezende ${ }^{3}$, José Roberto Mineo ${ }^{1}$ and Julia Maria Costa-Cruz ${ }^{1}$
}

\begin{abstract}
Introduction: Considering that alternative antigens for diagnosing neurocysticercosis continue to be a challenge because of the increasing difficulty in obtaining parasites from naturally infected pigs for preparation of Taenia solium homologous antigen, the aim of the present study was to evaluate the detergent (D) and aqueous (A) fractions from saline extract of Taenia saginata metacestodes for diagnosing neurocysticercosis. Methods: Taenia saginata was obtained from naturally infected bovines in the Triângulo Mineiro region, State of Minas Gerais, Brazil. The carcasses came from cold storage units and had been slaughtered in accordance with the inspection technique recommended by the Federal Inspection Service. The D and A fractions were obtained by using Triton X-114 (TX-114). Serum samples were obtained from 40 patients with a diagnosis of neurocysticercosis, 45 with other parasitic diseases and 30 from apparently normal individuals. IgG antibody levels were evaluated using the ELISA and immunoblotting assays. Results: The ELISA sensitivity and specificity were $95 \%$ and $73.3 \%$, when using saline extract; $95 \%$ and $82.6 \%$ for the D fraction; and $65 \%$ and $61.3 \%$ for the A fraction, respectively. The immunoblotting assay confirmed the ELISA results, such that the $\mathrm{D}$ fraction was more efficient than the other extracts, and the $70-68 \mathrm{kDa}$ component was immunodominant among neurocysticercosis patients. Conclusions: These results demonstrated that the $\mathrm{D}$ fraction from Taenia saginata metacestodes obtained using TX-114 can be used as a heterologous antigenic fraction in the immunoblotting assay for serologically diagnosing human neurocysticercosis, given its ability to select immunodominant antigens.
\end{abstract}

Key-words: Neurocysticercosis. Taenia solium. Taenia saginata. Heterologous antigen. Detergent extraction. Immunodiagnosis.

\section{RESUMO}

Introdução: Considerando que antígenos alternativos para o diagnóstico da neurocisticercose (NC) continua sendo um desafio devido ao aumento da dificuldade em se obter parasitas de suínos naturalmente infectados, para a preparação do antígeno homólogo de Taenia solium, o objetivo do presente estudo foi avaliar frações detergente (D) e aquosa (A), do extrato salino de metacestódeo de Taenia saginata para diagnóstico da NC. Métodos: Bovinos, naturalmente infectados com Taenia saginata, procedentes da região do Triângulo Mineiro, Estado de Minas Gerais, Brasil, foram obtidos de frigoríficos e abatidos de acordo com a técnica de inspeção recomendada pelo Serviço de Inspeção Federal. As frações D e A foram obtidas utilizando Triton X-114 (TX-114). Amostras de soro foram obtidas de 40 pacientes com diagnóstico de NC, 45 com diagnóstico de outras doenças parasitárias e 30 de indivíduos aparentemente normais. Níveis de IgG foram avaliados pelos testes ELISA e Imunoblotting. Resultados: A sensibilidade e especificidade do teste ELISA foram $95 \%$ e $73,3 \%$, quando utilizado o extrato salino, $95 \%$ e $82,6 \%$ para fração D, e $65 \%$ e $61,3 \%$ para a fração A, respectivamente. O ensaio Imunoblotting confirmou os resultados do teste ELISA, sendo a fração D mais eficiente que os outros extratos, observando-se que o componente $70-68 \mathrm{kDa}$ se comportou como imunodominante para os pacientes com NC. Conclusões: Estes resultados demonstraram que a fração D de metacestódeo de Taenia saginata obtida com TX-114 pode ser utilizada como fração antigênica heteróloga pelo Imunoblotting para o diagnóstico sorológico da NC humana, considerando sua habilidade para selecionar antígenos imunodominantes.

Palavras-chaves: Neurocisticercose. Taenia solium. Taenia saginata. Antígeno heterólogo. Extração detergente. Imunodiagnóstico.

1. Department of Immunology, Microbiology and Parasitology, Institute of Biomedical Sciences, Federal University of Uberlândia, Uberlândia, MG. 2. Department of Biological Sciences, Federal University of Goiás, Campus Catalão, GO. 3. Faculty of Veterinary Medicine, Federal University of Uberlândia, Uberlândia, MG, Brazil.

Address to: Dra. Julia Maria Costa-Cruz. Laboratório de Parasitologia/ICBIM/UFU. Av. Pará 1720, 38400-902 Uberlândia, MG, Brazil.

Tel: 5534 3218-2187

e-mail: costacruz@ufu.br

Received in 04/11/2009

Accepted in $12 / 03 / 2010$

\section{INTRODUCTION}

Neurocysticercosis (NC) is the most common infection of the human central nervous system and it is caused by the larval stage of the intestinal parasite Taenia solium. This disease affects millions of people worldwide, especially in areas with poor sanitation where humans and animals live in close contact, and in regions where meat inspection is lax ${ }^{1}$.

The major clinical manifestations of NC are seizures, intracranial hypertension and focal neurological deficits. Sequelae such as epilepsy, hydrocephalus and dementia can also occur ${ }^{2,3}$. Neuroimaging techniques have contributed towards greater diagnostic accuracy. Only the presence of cystic lesions showing the scolex has been considered pathognomonic ${ }^{4,5}$. These techniques are expensive and generally inaccessible in endemic rural situations. Consequently, various assays have been developed for detecting anticysticercal antibodies in serum, saliva and cerebrospinal fluids $(\mathrm{CSF})^{6-9}$.

Different antigenic extracts from Taenia solium metacestodes, such as saline extract, vesicle fluid, alkaline extract, scolex or membrane extracts have been used in the enzyme-linked immunosorbent assay (ELISA) for NC diagnosis and have shown differences in terms of sensitivity and specificity ${ }^{10-12}$. The immunoblotting (IB) assay has also been used for diagnosing NC, and different indices of sensitivity and specificity have been observed, depending on the antigen preparation used ${ }^{8,13-15}$.

Alternative antigens for $\mathrm{NC}$ immunodiagnosis continue to be a challenge because of the increasing difficulty in obtaining parasites from naturally infected pigs for preparation of Taenia solium homologous antigen ${ }^{16}$. Heterologous antigens from Taenia saginata have also been used with satisfactory results in ELISA and IB, and can be used as alternative antigens for diagnosing human $\mathrm{NC}^{17-19}$. Taenia saginata cysticerci in their cystic stage can be obtained in considerable quantities, 
because the habitual diet in many countries is mainly based on beef consumption. Although heterologous antigens from Taenia saginata metacestodes have been used with satisfactory results, there has been no research to test purification of these antigens with the aim of selecting antigens present in this helminth that are able to react with antibodies induced by Taenia solium-infected individuals. Crossreactivity has been demonstrated among helminths, particularly between Taenia and Echinococcus, which share the same antigenic components $^{20}$. Therefore, it is necessary to carry out procedures to select immunogenic components from saline extracts of Taenia saginata that are homologous to Taenia solium, but not shared by other helminths. Even though there have been previous reports on the advantages of recombinant antigens or synthetic peptides from Taenia solium and Taenia saginata ${ }^{21,22}$, it can be demonstrated that native antigens present better diagnostic performance, possibly due to post-translational modifications such as glycosylation pathways that are not present in the prokaryotic system.

The procedure using Triton X-114 (TX-114) fraction partitioning is a versatile and efficient purification technique. A solution of TX-114 nonionic surfactant is homogeneous at $0^{\circ} \mathrm{C}$ but separates into detergent (D) and aqueous (A) fractions above $20^{\circ} \mathrm{C}$. Integral membrane proteins of an amphiphilic nature are recovered in the $\mathrm{D}$ fraction and hydrophilic proteins are found exclusively in the A fraction ${ }^{23}$. Antigenic fractions purified from Taenia solium metacestodes by means of TX-114, especially the D fraction, have been shown to be efficient for diagnosing $\mathrm{NC}^{24}$.

The aim of the present study was to evaluate hydrophobic and hydrophilic fractions from Taenia saginata metacestodes obtained by means of TX-114 extraction for immunodiagnosis of human NC.

\section{METHODS}

\section{Patients and serum samples}

Serum samples were collected from 115 subjects selected by the Clinical Analysis Laboratory of the Clinical Hospital (Groups 1 and 2) and from the Parasitology Laboratory (Group 3) of the Federal University of Uberlândia, in the State of Minas Gerais, Brazil. Group 1 was formed by 40 patients who had been diagnosed with definitive NC, based on the presence of the clinical syndrome, evidence of the parasite by neuroimaging, epidemiological data and positive immunological tests, according to diagnostic criteria defined previously ${ }^{4}$. All the patients presented at least one type of clinical manifestation suggestive of NC such as: epilepsy (55\%), headache (50\%), dizziness $(27.5 \%)$, dementia (12.5\%), faintness (10\%) or hydrocephalus $(2.5 \%)$, and no signs or symptoms of cysticercosis in other organs. They presented evidence of parasite neuroimaging, with the following characteristics: 8 (20\%) vesicular; 15 (37.5\%) vesicular/calcified; and 17 (42.5\%) calcified metacestodes. All the patients came from or lived in an area where cysticercosis is endemic. At least two patients had had household contact with Taenia solium infection and they were tested positive using cerebrospinal fluid ELISA for detection of IgG anticysticercal antibodies, as previously described ${ }^{6}$.

Serum samples from Group 2 were obtained from 45 patients with other parasitoses: Ascaris lumbricoides (6), Echinococcus granulosus (6), Enterobius vermicularis (5), Ancylostoma duodenale or Necator americanus (5), Hymenolepis nana (4), Schistosoma mansoni (5), Strongyloides stercoralis (4), Taenia sp (8) and Trichuris trichiura (2). The Group 3 serum samples were from 30 apparently healthy volunteers, based on their clinical picture and three fecal samples that tested negative using the Lutz ${ }^{25}$ and Baermann ${ }^{26}$ parasitological methods. All these individuals came from endemic areas for cysticercosis and they did not present any evidence of household contact with Taenia solium infection or previous history of taeniasis or cysticercosis.

\section{Animals and parasites}

Taenia saginata was obtained from naturally infected bovines in the Triângulo Mineiro region, State of Minas Gerais, Brazil. The infected cattle came from abattoirs and they were slaughtered in accordance with the inspection technique recommended by the Federal Inspection Service. Taenia saginata metacestodes were obtained in their vesicular stage in considerable quantities by dissecting the muscles. These were then washed in saline solution $(0.15 \mathrm{M} \mathrm{NaCl})$ four times and stored at $-20^{\circ} \mathrm{C}$. Calcified Taenia saginata cysticerci were rejected.

\section{Antigen preparations}

Saline extract from Taenia saginata metacestodes was prepared as described by Oliveira et $\mathrm{al}^{18}$ The $\mathrm{D}$ and $\mathrm{A}$ fractions were obtained using a solution of TX-114 (Sigma Chem Co, St Louis, MO, USA), as described by Machado et $\mathrm{al}^{24}$, with modifications from the original procedure, as described by Bordier ${ }^{23}$. The saline extract of Taenia saginata metacestodes ( $8.4 \mathrm{mg}$ of total protein) was added to $1,680 \mu \mathrm{l}$ of Tris-buffered saline (10mM Tris- $\mathrm{HCl}, \mathrm{pH} 7.4,150 \mathrm{mM} \mathrm{NaCl})$ and $1 \% \mathrm{TX}-114$. This mixture was incubated $\left(0^{\circ} \mathrm{C}, 10 \mathrm{~min}\right)$ and added carefully to a sucrose mixture $(5.5 \mathrm{ml}$ of Tris plus $6 \%$ sucrose and $0.06 \% \mathrm{TX}-114)$. The mixture was incubated $\left(37^{\circ} \mathrm{C}, 10 \mathrm{~min}\right)$, followed by centrifugation $\left(3,000 \mathrm{~g}, 25^{\circ} \mathrm{C}, 10 \mathrm{~min}\right)$. The upper fraction was collected and $1 \% \mathrm{TX}-114$ was added and incubated $\left(0^{\circ} \mathrm{C}, 10 \mathrm{~min}\right)$. This solution was again added carefully to the sucrose mixture used previously, incubated $\left(37^{\circ} \mathrm{C}, 10 \mathrm{~min}\right)$ and centrifuged $(3,000 \mathrm{~g}$, $25^{\circ} \mathrm{C}, 10 \mathrm{~min}$ ). The supernatant was reserved for separation of the A fraction and the pellet consisted of the $\mathrm{D}$ fraction. The recovered supernatant was rinsed with $2 \% \mathrm{TX}-114$ in a separate tube without a sucrose cushion, incubated at $0^{\circ} \mathrm{C}$ for $10 \mathrm{~min}$ and then at $37^{\circ} \mathrm{C}$ for $10 \mathrm{~min}$, followed by centrifuging $\left(3,000 \mathrm{~g}, 25^{\circ} \mathrm{C}, 10 \mathrm{~min}\right)$. The supernatant of this solution comprised the A fraction. The purified proteins ( $\mathrm{D}$ and $\mathrm{A}$ fractions) were precipitated $(1: 2 ; \mathrm{v} / \mathrm{v})$ in cold acetone at $4^{\circ} \mathrm{C}$ overnight and centrifuged $\left(3,000 \mathrm{~g}, 4^{\circ} \mathrm{C}, 30 \mathrm{~min}\right)$. The supernatants were discarded carefully and the precipitates were resuspended in $1 \mathrm{ml}$ of Tris-buffered saline. The protein content of each antigen preparation was determined in accordance with Lowry et $\mathrm{al}^{27}$, using bovine serum albumin as the standard protein, and the aliquots were stored at $-20^{\circ} \mathrm{C}$.

\section{Enzyme-linked immunosorbent assay}

ELISA was carried out to detect IgG antibodies to Taenia saginata metacestodes, as previously described by Oliveira et $\mathrm{al}^{18}$. Optical densities (OD) were determined at $492 \mathrm{~nm}$ in an ELISA reader ( $\mathrm{Tp}$ Reader, Thermoplate, China). The cutoff values were established using the mean $\mathrm{OD}$ of three non-reactive serum samples plus two standard deviations, as described by Bassi et $\mathrm{al}^{28}$. The reactive index (RI) was calculated as the ratio between optical density and cutoff, as described by Pardini et $\mathrm{al}^{16}$. All the samples showing RI > 1 were considered positive. 


\section{SDS-polyacrylamide gel electrophoresis}

The antigens were diluted $(\mathrm{v} / \mathrm{v})$ in sample buffer and, after boiling at $100^{\circ} \mathrm{C}$ for $3 \mathrm{~min}$, all antigens and molecular weight markers (Sigma) were subjected to sodium dodecyl sulfate-polyacrylamide gel electrophoresis (SDS-PAGE) at $12 \%$ under non-reducing conditions, as previously described by Laemmli ${ }^{29}$. The antigen bands and molecular weight markers were viewed by means of silver staining, as described by Friedman ${ }^{30}$, and the relative molecular masses were estimated using a logarithmic plot of the migration of the molecular weight standards included in each gel.

\section{Immunoblotting}

Antigen preparations were subjected to electrophoresis and transferred to nitrocellulose membranes $(0.45 \mathrm{~mm}$, Sigma $)$, as previously described by Towbin et $\mathrm{a}^{31}$, by using a transfer apparatus (Omniphor, England). The IB assay was performed as described by Oliveira et $\mathrm{al}^{18}$, by using serum samples diluted at 1:100 and peroxidase-labeled goat anti-human IgG conjugate whole molecule (Sigma) diluted 1:1,500 in $1 \%$ PBS-TM. The strips were developed for $3 \mathrm{~min}$ in substrate solution containing hydrogen peroxide and 3,3-diaminobenzidine tetrahydrochloride (DAB-Sigma) in PBS. The reaction was stopped with distilled water and reactions were considered positive if clearly defined bands appeared. The relative molecular masses of the recognized bands were determined by comparison with molecular markers (Sigma).

\section{Data analysis}

The geometric means (gm) of RI were calculated for each subject group and antigen extract. The difference between pairs of proportions was calculated by means of a binomial test ( $Z$ statistics). The data were analyzed using BioStat 2.0 software. The null hypothesis was rejected when $p<0.05$. Sensitivity, specificity and diagnostic efficiency (DE) were calculated in accordance with Barbieri et $\mathrm{al}^{32}$, and the Youden Index (YI) was determined in accordance with Youden ${ }^{33}$.

\section{Ethical}

This study was approved by the Ethics Committee of the Federal University of Uberlândia.

\section{RESULTS}

\section{Enzyme-linked immunosorbent assay}

All samples were tested by means of ELISA using the three antigen preparations (Figure 1). In Group 1, statistical differences were found between the saline extract and $\mathrm{A}$ fraction, and between the $\mathrm{D}$ and $\mathrm{A}$ fractions $(p<0.05)$. In Group 2, a statistical difference was found only between the D and A fractions $(p<0.05)$. No statistical difference was observed in Group 3. The sensitivity for detection of IgG antibodies to Taenia saginata was $95 \%$ for both saline extract and D fraction antigens and $65 \%$ for A fraction. In Group 2, $42.2 \%$ and $64.4 \%$ of the serum samples were positive for saline extract and A fraction antigens, respectively. Only $28.9 \%$ of the serum samples of this group were tested positive for $\mathrm{D}$ fraction. Crossreactivity in ELISA for Group 2 was predominantly found in serum samples of patients with Echinococcus granulosus, Ascaris lumbricoides and Hymenolepis nana (Table 1). All serum samples from Group 3 were negative for both $\mathrm{D}$ and $\mathrm{A}$ fractions, while $3.3 \%$ of the samples

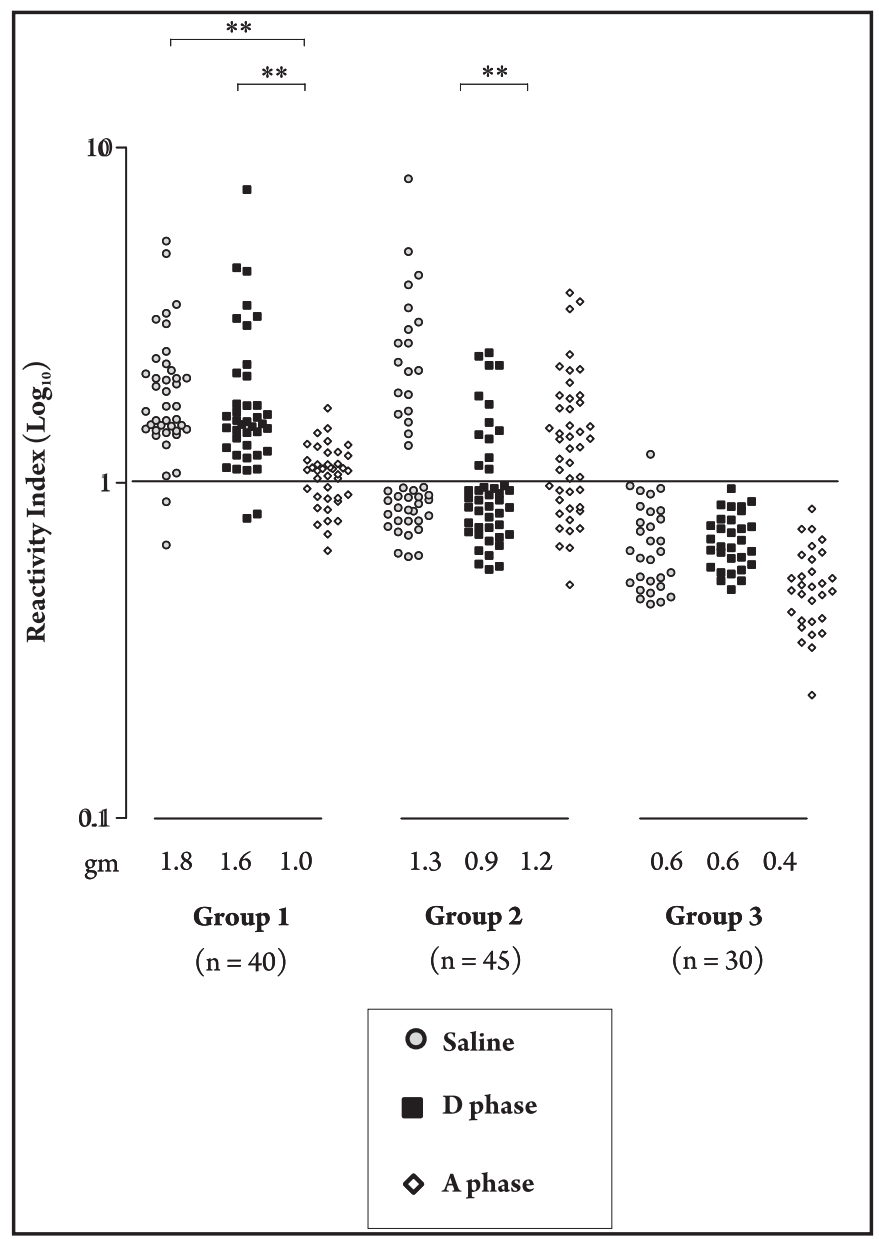

FIGURE 1 - Detection of IgG antibodies from anti-Taenia solium metacestodes in serum samples from patients with a definitive diagnosis of NC (Group 1; $n=40$ ), patients with other parasitoses (Group $2 ; n=45$ ) and apparently healthy individuals (Group 3; $\mathbf{n}=30$ ), by means of ELISA using the saline extract (Saline), detergent fraction (D phase) and aqueous fraction (A phase) antigens from Taenia saginata metacestodes. The horizontal line indicates the reactivity cutoff of the index $(\mathrm{RI}=1) .^{*} \mathrm{p}<0.05$.

TABLE 1 - Reactivity from serum samples of patients with parasitoses other than neurocysticercosis (Group 2, $n=45)$ using saline extract (Saline), detergent phase (D phase) and aqueous phase (A phase) antigens from Taenia saginata metacestodes, by means of ELISA.

\begin{tabular}{|c|c|c|c|c|c|c|c|}
\hline \multirow[b]{2}{*}{ Parasites } & \multirow{2}{*}{$\begin{array}{l}\text { Number of serum } \\
\text { samples examined }\end{array}$} & \multicolumn{2}{|c|}{ Saline } & \multicolumn{2}{|c|}{ D phase } & \multicolumn{2}{|c|}{ A phase } \\
\hline & & $\mathrm{n}+$ & $\overline{\%}$ & $\mathrm{n}+$ & $\%$ & $\mathrm{n}+$ & $\%$ \\
\hline Ascaris lumbricoides & 6 & 5 & 83.3 & 4 & 66.7 & $\overline{6}$ & 100 \\
\hline Echinococcus granulosus & 6 & 6 & 100 & 6 & 100 & 6 & 100 \\
\hline Enterobius vermicularis & 5 & 2 & 40 & 0 & 0 & 5 & 100 \\
\hline Hymenolepis nana & 4 & 3 & 75 & 3 & 75 & 3 & 75 \\
\hline Ancylostoma duodenale or Necator americanus & 5 & 2 & 40 & 0 & 0 & 5 & 100 \\
\hline Schistosoma mansoni & 5 & 0 & 0 & 0 & 0 & 1 & 20 \\
\hline Strongyloides stercoralis & 4 & 1 & 25 & 0 & 0 & 3 & 75 \\
\hline Taenia sp & 8 & 0 & 0 & 0 & 0 & 0 & 0 \\
\hline Trichuris trichiura & 2 & 0 & 0 & 0 & 0 & 0 & 0 \\
\hline
\end{tabular}

$\mathrm{n+:}$ positive samples. 
from this group tested positive for the saline extract antigen. ELISA specificity was $73.3 \%$ (saline extract), $82.6 \%$ (D fraction) and $61.3 \%$ (A fraction), whereas the diagnostic efficiency and Youden index were $83.9 \%$ and 0.74 (saline extract), $88.5 \%$ and 0.80 (D fraction), and $72.8 \%$ and 0.46 (A fraction), respectively.

\section{Electrophoresis of saline extract and fractionated antigens}

As demonstrated in Figure 2A, the electrophoretic profile of the saline extract and A fraction antigens from Taenia saginata metacestodes in silver-stained SDS-PAGE showed several bands, while the $\mathrm{D}$ fraction showed four clearly defined components with apparent molecular sizes of 70, 64, 50 and $39 \mathrm{kDa}$.

\section{Immunoblotting}

A representative IB is demonstrated in Figure 2B. The immunoreactive antigenic bands recognized from serum samples of patients in Groups 1 and 2 varied from 116 to $24 \mathrm{kDa}$ for the saline extract and $\mathrm{D}$ fraction antigens and 116 to $13 \mathrm{kDa}$ when using the A fraction (Figure 3). When using the $\mathrm{D}$ fraction, it was found that patients with a definitive diagnosis of NC reacted strongly with the $70-68 \mathrm{kDa}$ components (Figure 3A). On the other hand, patients with Echinococcus granulosus infection showed no reactivity with the 70-68kDa components, even though the presence of various reactive components was observed $(116,110,97,87,64,45,42-39$ and $24 \mathrm{kDa}$ ) (Figure 3B). For the A fraction, reactivity was observed mostly for high molecular weight components (116 and $110 \mathrm{kDa})$.

\section{A}

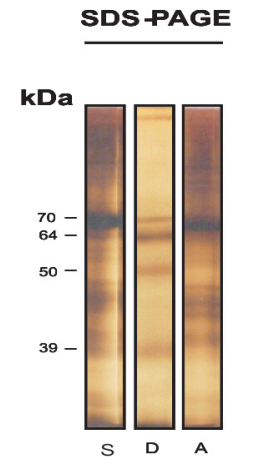

B

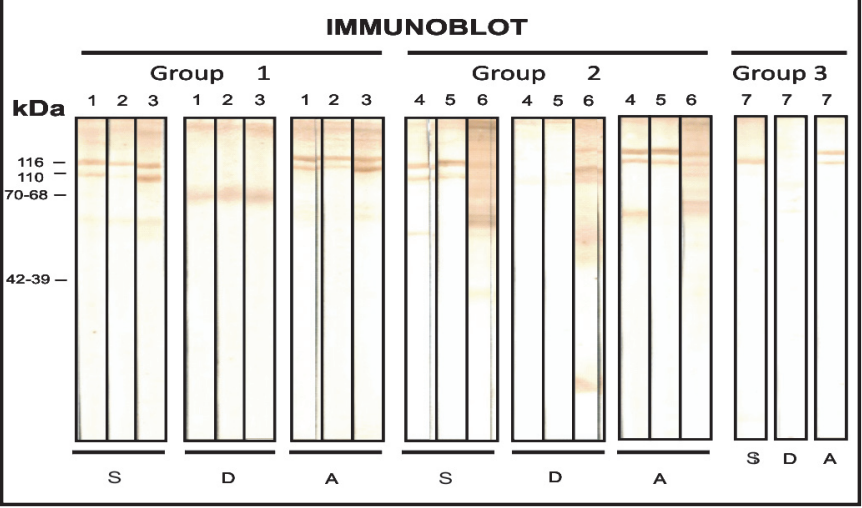

FIGURE 2-A) Electrophoretic profile in SDS-PAGE at 12\%, with silver staining, and immunoblot assay on saline extract (S), detergent fraction (D) and aqueous fraction (A) antigens from Taenia saginata metacestodes.B) Representative immunoblotting of serum samples from patients with a definitive diagnosis of neurocysticercosis (Group 1 ; lanes 1 to 3), patients presenting other parasitoses (Group 2; Ascaris lumbricoides lane 4; Hymenolepis nanalane 5; Echinococcus granulosuslane 6) and apparentlyhealthy individuals (Group 3; lane 7). Molecular masses are given on the left in kDa.

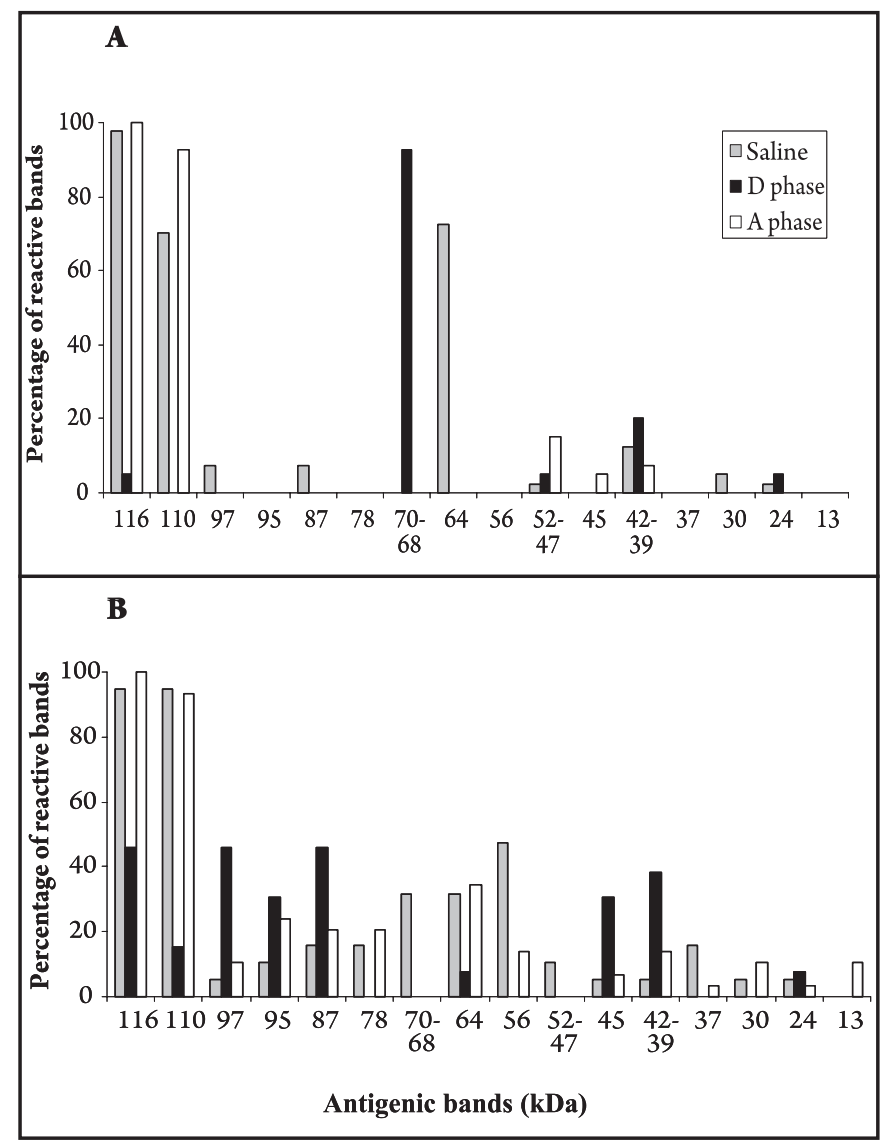

FIGURE 3 - Percentage reactivity of serum samples in immunoblotting using the saline extract (Saline), detergent fraction (D phase) and aqueous fraction (A phase) antigens from Taenia saginata metacestodes. (A) Group 1: patients with a definitive diagnosis of neurocysticercosis, (B) Group 2: patients with other parasitoses.

\section{DISCUSSION}

The use of heterologous antigens to diagnose human NC has been described mainly in relation to Taenia crassiceps antigen, in both serum and CSF samples ${ }^{8,34-36}$. Furthermore, high sensitivity in ELISA and IB tests when using saline extract obtained from Taenia saginata metacestodes has already been demonstrated ${ }^{18,19}$.

In the present study, we demonstrated for the first time in the literature that partitioning of saline extract from Taenia saginata metacestodes into two fractions, a detergent (D) and an aqueous (A) fraction, using TX-114, is a useful procedure for diagnosing human NC. The major advantages of using antigens purified by TX-114 solution are the minimal cost of producing them in the laboratory, simple and easy extraction, high efficiency, speed and lower toxicity to the environment than from extractions involving organic solvents. Satisfactory results have been obtained using D fraction antigens, in which the performance of integral membrane antigens recovered from the D fraction during TX-114 treatment has shown their promise as candidate antigens in ELISA-based serodiagnosis, with substantial sensitivity, specificity and safety ${ }^{24}$.

In the present study, the $\mathrm{D}$ fraction was shown to be more specific than the other extracts, while none of the serum samples from healthy individuals were reactive. The diagnostic efficiency and Younden index confirmed the good performance by ELISA, using the $\mathrm{D}$ fraction from Taenia saginata metacestodes for diagnosing 
human NC. Similar results have been obtained from partitioning of saline extract from Taenia solium metacestodes ${ }^{24}$.

Because of the lower sensitivity and specificity of the A fraction obtained from Taenia saginata metacestodes, it is not useful for detecting anti-Taenia solium metacestode IgG antibodies for serologically diagnosing human NC. Similar results have been obtained with the aqueous fraction from Taenia solium metacestodes ${ }^{24}$.

In the present study, when using the D fraction purified with TX-114, cross-reactivity in ELISA occurred mainly in serum samples from patients with Echinococcus granulosus, Ascaris lumbricoides and Hymenolepis nana. On the other hand, when using the A fraction, cross-reactivity was observed for the majority of the serum samples from patients with other parasites, except for Taenia sp and Trichuris trichiura. These results suggest that ELISA can be used as a screening test, whereas IB is a confirmatory assay.

Previous study had demonstrated that Taenia sp metacestode antigens were likely to be stage specific, since there was high sensitivity with serum samples from individuals infected with metacestodes and high specificity in individuals with Taenia sp infection ${ }^{18}$.

The presence of shared antigenic components between Taenia sp and Echinococcus sp, which belong to the same family (Taeniidae), has been demonstrated and these antigens are probable responsible for the cross-reactivity between these parasites ${ }^{20}$. Seven immunodominant proteins $(135,100,86,64,39,35$ and $24 \mathrm{kDa})$ had already been recognized in serum samples from individuals infected with Echinococcus granulosus, in IB using vesicle liquid from Taenia solium metacestodes ${ }^{37}$. In the present study, various proteins from saline antigen were also recognized in patients infected with Echinococcus granulosus, as demonstrated previously by our group ${ }^{18}$ in relation to using Taenia saginata metacestodes. In addition, cross-reactivity among individuals infected by Hymenolepis nana was observed, which had been shown in a previous study ${ }^{11}$. This is related to the phylogenetic proximity between Taenia sp and Hymenolepis sp (Taeniidae family) and to the presence of shared antigenic components between these species ${ }^{38}$.

In the present study, the higher sensitivity and specificity of IB using the D fraction was related to the expression of the 70$68 \mathrm{kDa}$ band, which was considered to be an immunodominant component in diagnosing NC patients by means of Taenia saginata metacestodes. Accordingly, components of $70-50 \mathrm{kDa}$ have been already reported in our previous study using the $\mathrm{D}$ fraction from Taenia solium metacestodes, showing satisfactory sensitivity and specificity levels ${ }^{24}$. Thus, future studies, particularly those to be carried out under field conditions, should consider the possibility of using purified $70-68 \mathrm{kDa}$ components in easy-to-perform tests, such as immunodot assays.

In conclusion, the results presented here demonstrated that the D fraction from Taenia saginata metacestodes obtained using TX-114 can be used as heterologous antigenic fraction in immunoblotting for serologically diagnosing human NC, given its ability to select immunodominant antigens.

\section{CONFLICT OF INTEREST}

The authors declare that there is no conflict of interest.
FINANCIAL SUPPORT

\author{
CNPq, CAPES, FAPEMIG.
}

\section{REFERENCES}

1. Sciutto E, Fragoso G, Fleury A, Laclette JP, Sotelo J, Aluja A, et al. Taenia solium disease in humans and pigs: an ancient parasitosis disease rooted in developing countries and emerging as a major health problem of global dimensions. Microbes Infect 2000; $2: 1875-1890$.

2. Takayanagui OM, Odashima NS. Clinical aspects of neurocysticercosis. Parasitol Int 2006; 55(suppl):111-115.

3. Sinha S, Sharma BS. Neurocysticercosis: a review of current status and management. J Clin Neurosci 2009; 16:867-876.

4. Del Brutto OH, Rajshekhar V, White Jr AC, Tsang VC, Nash TE, Takayanagui OM, et al. Proposed diagnostic criteria for neurocysticercosis. Neurology 2001; 57:177-183.

5. Castillo M. Imaging of neurocysticercosis. Semin Roentgenol 2004; 39:465 473

6. Costa JM, Ferreira AW, Makino MM, Camargo ME. Spinal fluid immunoenzymatic assay (ELISA) for neurocysticercosis. Rev Inst Med Trop Sao Paulo 1982; 24:337341

7. Sotelo J, Del Brutto OH. Brain Cysticercosis. Arch Med Res 2000; 31:3-14

8. Barcelos IS, Mineo JR, de Oliveira Silva DA, Ferreira MS, de Moura LP, Biondi GF, et al. Detection of IgG in cerebrospinal fluid for diagnosis of neurocysticercosis: evaluation of saline and SDS extracts from Taenia solium and Taenia crassiceps metacestodes by ELISA and immunoblot assay. Trop Med Int Health 2001; 6:219-226

9. Arruda GC, Quagliato EMAB, Rossi CL. Intrathecal synthesis of specific immunoglobulin $\mathrm{G}$ antibodies in neurocysticercosis: Evaluation of antibody concentrations by enzyme-linked immunosorbent assay using a whole cysticercal extract and cyst vesicular fluid as antigens. Diagn Microbiol Infect Dis 2006; 54:45-49.

10. Costa JM. Immunoenzymatic test (ELISA) in the diagnosis of neurocysticercosis: study of various antigenic extracts in the detection of $\mathrm{IgG}$ antibodies in serum and cerebrospinal fluid samples. Arq Neuropsiquiatr 1986; 44:15-31.

11. Shiguekawa KY, Mineo JR, de Moura LP, Costa-Cruz JM. ELISA and western blotting tests in the detection of IgG antibodies to Taenia solium metacestodes in serum samples in human neurocysticercosis. Trop Med Int Health 2000; 5:443-449.

12. Ishida MM, Peralta RH, Livramento JA, Hoshino-Shimizu S, Peralta JM, Vaz AJ Serodiagnosis of neurocysticercosis in patients with epileptic seizure using ELISA and immunoblot assay. Rev Inst Med Trop Sao Paulo 2006; 48:343-346.

13. Tsang VC, Brand JA, Boyer AE. An enzyme-linked immunoelectrotransfer blot assay and glycoprotein antigens for diagnosing human cysticercosis (Taenia solium). J Infect Dis 1989; 159:50-59.

14. Simac C, Michel P, Andriantsimahavandy A, Esterre P, Michault A. Use of enzymelinked immunosorbent assay and enzyme-linked immunoelectrotransfer blot for the diagnosis and monitoring of neurocysticercosis. Parasitol Res1995; 81:132-136.

15. Proaño-Narvaez JV, Meza-Lucas A, Mata-Ruiz O, García-Jerónimo RC, Correa D. Laboratory diagnosis of human neurocysticercosis: double-blind comparison of enzyme-linked immunosorbent assay and electroimmunotransfer blot assay. J Clin Microbiol 2002; 40: 2115-2118.

16. Pardini AX, Peralta RH, Vaz AJ, Machado LR, Peralta JM. Use of Taenia crassiceps cysticercus antigen preparations for detection of antibodies in cerebrospinal fluid samples from patients with neurocysticercosis (Taenia solium). Clin Diag Lab Immunol 2002; 9:190-193.

17. MorakoteN,Nawacharoen W,Sukonthasun K, ThammasonthiW, Khamboonruang C. Comparison of cysticercus extract, cyst fluid and Taenia saginata extract for use in ELISA for serodiagnosis of neurocysticercosis. Southeast Asian J Trop Med Public Health 1992; 23:77-81

18. Oliveira HB, Machado GA, Cabral DD, Costa-Cruz JM. Application of Taenia saginata metacestodes as alternative antigen for the serological diagnosis of human neurocysticercosis. Parasitol Res 2007; 101:1007-1013. 
19. Oliveira HB, Machado GA, Gonçalves-Pires MR, Moura LP, Costa-Cruz JM. Saline extract of Taenia saginata metacestodes as an alternative antigen for the immunodiagnosis of neurocysticercosis in human cerebrospinal fluid. Parasitol Res 2009; 105:169-174.

20. Ishida MM, Rubinsky-Elefant G, Ferreira AW, Hoshino-Shimizu S, Vaz AJ. Helminth antigens (Taenia solium, Taenia crassiceps, Toxocara canis, Schistosoma mansoni and Echinococcus granulosus) and cross-reactivities in human infections and immunized animals. Acta Trop 2003; 89:73-84.

21. Fleury A, Beltran C, Ferrer E, Garate T, Harrison LJ, Parkhouse RM, et al. Application of synthetic peptides to the diagnosis of neurocysticercosis. Trop Med Int Health 2003; 8:1124-1130.

22. Bueno EC, Scheel CM, Vaz AJ, Machado LR, Livramento JA, Takayanagui OM, et al. Application of synthetic $8-\mathrm{kD}$ and recombinant GP50 antigens in the diagnosis of neurocysticercosis by enzyme-linked immunosorbent assay. Am J Trop Med Hyg 2005; 72:278-283.

23. Bordier C. Phase separation of integral membrane proteins in Triton X-114 solution. J Biol Chem 1981; 256:1604-1607.

24. Machado GA, Santiago FM, Mineo JR, Costa-Cruz JM. Assessment of antigenic fractions of varying hydrophobicity from Taenia solium metacestodes for the diagnosis of human neurocysticercosis. Trop Med Int Health 2007; 12:1369-1376.

25. Lutz AV. Schistosoma mansoni e a schistosomose, segundo observações feitas no Brasil. Mem Inst Oswaldo Cruz 1919; 11:121-125.

26. Baermann G. Eine einfache Methode zur Auffinfung von Ankylostomun (Nematoden) Larven in Erdproben. Mededeel. mit H. Geneesk. Batavia, Lab. Weltevreden Feestbundel; 1917. p. 41-47.

27. Lowry OH, Rosebrough NJ, Farr AL, Randall RJ. Protein measurement with the Folin phenol reagent. J Biol Chem1951; 193:265-275.

28. Bassi GE, Ishiki DK, Ferreira AW, Camargo ME. A reação imunoenzimática para cisticercose no líquido cefalorraquiano - considerações sobre o limiar de reatividade. Rev Bras Patol Clin1991; 27:49-52.

29. Laemmli UK. Cleavage of structural proteins during the assembly of the head of bacteriophage T4. Nature 1970; 227:680-685.

30. Friedman RD. Comparison of four different silver-staining techniques for salivary protein detection in alkaline polyacrylamide gels. Anal Biochem 1982; 126:346-349.

31. Towbin H, Staehelin T, Gordon J. Electrophoretic transfer of proteins from polyacrylamide gels to nitrocellulose sheets: procedure and some applications. Proc Natl Acad Sci USA 1979; 76:4350-4354.

32. Barbieri M, Fernández V, González G, Luaces VM, Nieto A. Diagnostic evaluation of a synthetic peptide derived from a novel antigen $B$ subunit as related to other available peptides and native antigens used for serology of cystic hydatidosis. Parasite Immunol 1998; 20:51-61.

33. Youden WJ. Index for rating diagnosis tests. Cancer 1950; 3:32-35.

34. Larralde C, Montoya RM, Sciutto E, Diaz ML, Govezensky T, Coltorti E. Deciphering western blots of tapeworm antigens (Taenia solium, Echinococcus granulosus, and Taenia crassiceps) reacting with sera from neurocysticercosis and hydatid disease patients. Am J Trop Med Hyg 1989; 40:282-290.

35. Vaz AJ, Nunes CM, Piazza RM, Livramento JA, da Silva MV, Nakamura PM, et al. Immunoblot with cerebrospinal fluid from patients with neurocysticercosis using antigen from cysticerci of Taenia solium and Taenia crassiceps. Am J Trop Med Hyg1997; 57: 354-357.

36. Barcelos IS, Ferreira MS, Moura LP, Biondi GF, Costa-Cruz JM. Use of the paired samples (cerebrospinal fluid and serum) in immunodiagnostic of active and inactive human neurocysticercosis. Mem Inst Oswaldo Cruz 2005; 100:427-429.

37. Kong Y, Kang SY, Cho SY, Min DY. Cross-reacting and specific antigens components in cystic fluid from metacestodes of Echinococcus granulosus and Taenia solium. Korean J Parasitol 1989; 27:131-139.

38. Montenegro T, Gilman RH, Castillo R, Tsang V, Brandt J, Guevara A, et al. The diagnostic importance of species-specific and cross-reactive components of Taenia solium, Echinococcus granulosus, and Hymenolepis nana. Rev Inst Med Trop Sao Paulo 1994; 36: 327-334 